\title{
Conceptual model for the origin of high radon levels in spring waters - the example of the St. Placidus spring, Grisons, Swiss Alps
}

\author{
François Gainon*, Nico Goldscheider \& Heinz Surbeck
}

Key words: Radon, radium, iron hydroxides, groundwater, crystalline rocks, Swiss Alps

\section{ABSTRACT}

A variety of geological, hydrochemical and isotopic techniques were applied to explain the origin of exceptionally high radon levels in the St.Placidus spring near the city of Disentis in the Swiss Alps, where an average of $650 \mathrm{~Bq} / \mathrm{L}{ }^{222} \mathrm{Rn}$ was measured. ${ }^{222} \mathrm{Rn}$ is a radioactive noble gas with a half-life of 4 days, which results from the disintegration of radium $\left({ }^{226} \mathrm{Ra}\right)$. The high radon levels can neither be explained by generally increased radium content in the fractured aquifer rock (orthogneiss), nor by the radium concentration in the spring water. It was possible to show that there must be a productive radium reservoir inside the aquifer but very near to the spring. This reservoir mainly consists of iron and manganese oxides and hydroxides, which precipitate in a zone where reduced, iron-rich groundwaters mix occasionally with oxygen-rich, freshly infiltrated rainwater or meltwater. The iron, as well as the reduced and slightly acid conditions, can be attributed to pyrite oxidation in the recharge area of the spring. Radium cations strongly adsorb and accumulate on such deposits, and generate radon, which is then quickly transported to the spring with the flowing groundwater.
RESUME

La source St. Placidus de Disentis, dans les Alpes Suisses, montre des teneurs en ${ }^{222} \mathrm{Rn}$ particulièrement élevées, en moyenne $650 \mathrm{~Bq} / \mathrm{l}$. L'origine de cette activité a été investiguée par des méthodes géologiques, hydrochimiques et isotopiques. Le ${ }^{222} \mathrm{Rn}$ est un gaz noble radioactif, d'une période de 4 jours, qui est produit lors de la désintégration $\mathrm{du}^{226} \mathrm{Ra}$. L'activité importante du radon ne peut pas être expliquée par des teneurs élevées en radium contenu dans la roche ou dissous dans l'eau de l'aquifère fissuré. Le radon provient plutôt d'un réservoir de radium situé dans l'aquifère, à proximité de l'exutoire. Ce réservoir se présente sous la forme de dépôts secondaires d'oxydes et d'hydroxydes de fer et de manganèse qui précipitent dans une zone où les eaux riches en fer se mélangent ponctuellement à des eaux météoriques fraîchement infiltrées et riches en oxygène. Les teneurs élevées en fer, ainsi que le caractère réduit et relativement acide de l'eau, semble provenir de l'oxydation de la pyrite, abondante dans la zone de recharge. Le radium est adsorbé de façon très efficace sur les dépôts d'hydroxydes de fer et de manganèse et produit du radon, très soluble dans l'eau, qui est ensuite transporté, via le flux, jusqu'à l'exutoire.

\section{Introduction}

The water of the St. Placidus spring contains one of the highest concentrations of radon $\left({ }^{222} \mathrm{Rn}\right)$ measured so far in any Swiss spring. This radioactive noble gas is part of the ${ }^{238} \mathrm{U}$ decay chain and originates from the disintegration of radium $\left({ }^{226} \mathrm{Ra}\right)$. The aim of this study is to explain the origin of radon in the spring water, and to use the relevant radioisotopes of the uranium decay chain as natural tracers to better characterise groundwater flow and geochemical processes in hydrogeological systems, particularly crystalline rock aquifers. The behaviour of uranium, radium and radon is also of public health interest due to their radiotoxicity; exposure to these radioisotopes has the potential to cause adverse health effect (UNSCEAR 2000).

St.Placidus spring is situated in a small valley near the city of Disentis in the eastern Swiss Alps. The first mention of the use of this spring dates from the $17^{\text {th }}$ century (Müller 1971).
Up until the end of the $19^{\text {th }}$ century, people believed in its therapeutic properties due to the red colour resulting from the precipitation of iron hydroxides at the spring outlet. In the $20^{\text {th }}$ century, initial radon measurements showed high concentrations, prompting a new interest in this radioactive property. Hirschi (1920) attributed the observed radon levels in the water to the high content of radium in the rocks surrounding the spring. In 1952, the St. Placidus spring was developed to supply the baths of the Hotel Disentiserhof, via a 1200 m conduit. Today, the water is no longer used for that purpose but freely discharges into a nearby stream.

\section{Radon, radium and uranium in hydrogeological systems}

Radon occurs in three isotopic forms, ${ }^{222} \mathrm{Rn},{ }^{220} \mathrm{Rn}$ (thoron) and ${ }^{219} \mathrm{Rn}$ (actinon). The half-lives of these isotopes are 3.82 days, 54.5 seconds and 3.9 seconds, respectively. Due to the

Centre of Hydrogeology (CHYN), University of Neuchâtel, 11 Rue Emile-Argand, CH-2009 Neuchâtel, Switzerland.

*Corresponding Author: francois.gainon@unine.ch 


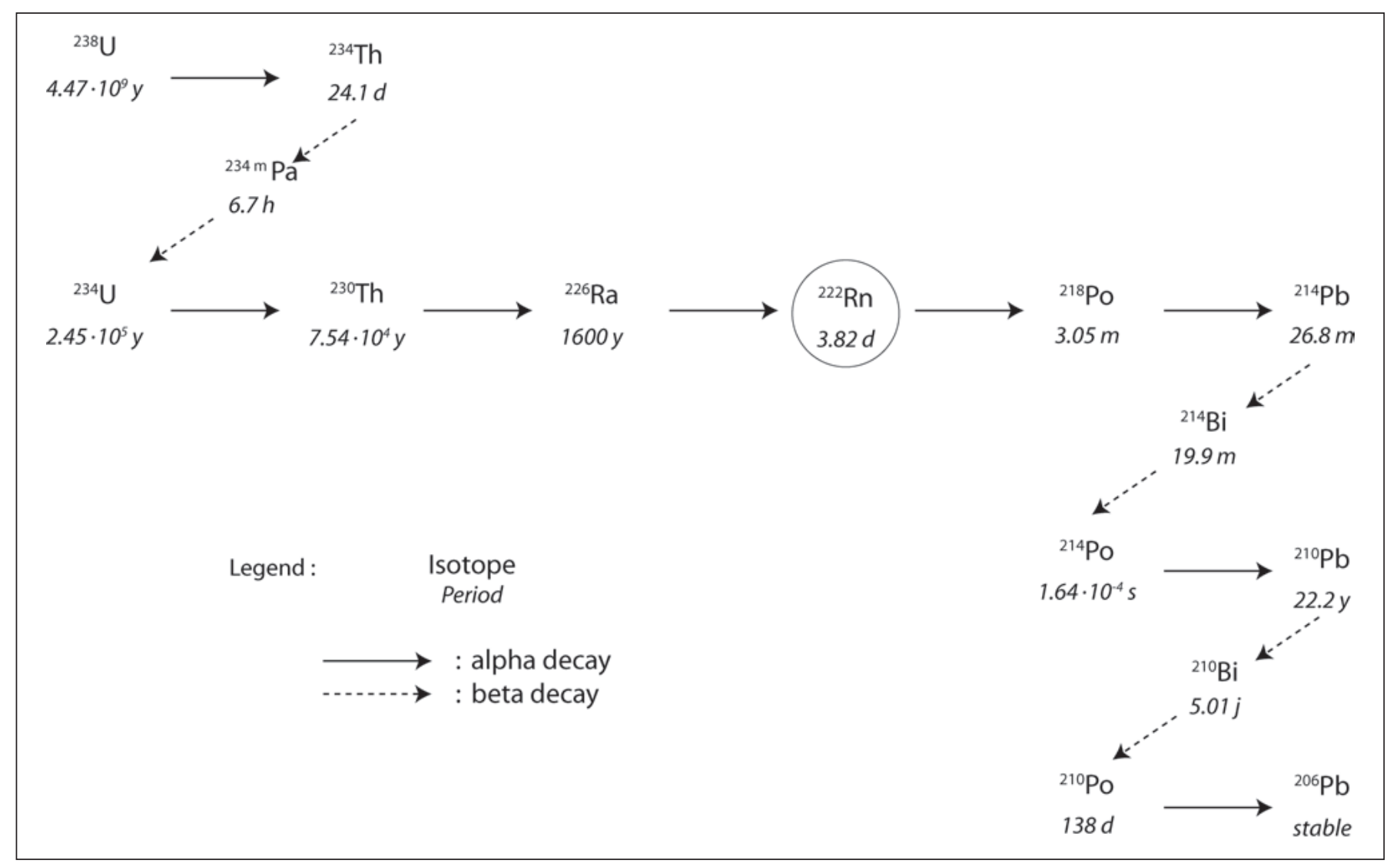

Fig. 1. Illustration of the ${ }^{238} \mathrm{U}$ decay chain. ${ }^{222} \mathrm{Rn}$ is the daughter of ${ }^{226} \mathrm{Ra}$ and has a period of 3.82 days.

very short periods of thoron and actinon, ${ }^{222} \mathrm{Rn}$ is the most frequently used radon isotope in hydrogeology. The transit times in hydrogeological systems are highly variable and typically range between a few days and thousands of years (Etcheverry \& Perrochet 2000). The half-life of ${ }^{222} \mathrm{Rn}$ is near the lower end of this range and after about 3-5 periods or 12-20 days, the radon concentration in water usually drops below the analytical detection limit. Radon is thus a useful time-tracer for hydrogeological systems with relatively short flow distances and/or high flow velocities (e.g. karst; Eisenlohr \& Surbeck 1995). Chemically, radon is inert and is the most soluble element of the noble gas group. Its solubility is expressed with the Oswald coefficient, $k$, representing the equilibrium between the gas concentration in a liquid phase $\left(\mathrm{C}_{\mathrm{l}}\right)$ and the gas concentration in a gas phase $\left(\mathrm{C}_{\mathrm{g}}\right)$ (Clever 1979).

$$
\mathrm{k}=\frac{\mathrm{C}_{\mathrm{l}}}{\mathrm{C}_{g}} \quad \text { At } 20^{\circ} \mathrm{C}, \mathrm{k}=0.26
$$

${ }^{226} \mathrm{Ra}$ is the mother of ${ }^{222} \mathrm{Rn}$, (Fig. 1) and has a period of 1600 years. Radium belongs to the alkaline earth metal group and has a valence of 2 . Therefore, it generally forms bivalent cations $\left(\mathrm{Ra}^{2+}\right)$ in natural environments, which behave chemically similar to $\mathrm{Ba}^{2+}, \mathrm{Sr}^{2+}, \mathrm{Ca}^{2+}$ and $\mathrm{Mg}^{2+}$. The mobility of radi- um in water is limited by the solubility of its carbonate and sulphate species, coprecipitation with $\mathrm{CaCO}_{3}$ and adsorption on iron and manganese oxides and hydroxides (short: Fe/Mn (hydr)oxides). Therefore, radium is significantly more mobile under reducing and acid conditions (Albu et al. 1997; Ames et al. 1983; Langmuir \& Riese 1985; Martin et al. 2003; Szabo \& Zapecza 1991). Several studies revealed a positive correlation between radium and salinity or chloride (Gascoyne 1989; Herczeg et al. 1988; Lauria et al. 2004; Sturchio et al. 2001), and between high radium content and low $\mathrm{pH}$ (Almeida et al. 2004).

Two isotopes of uranium $\left({ }^{238} \mathrm{U}\right.$ and $\left.{ }^{234} \mathrm{U}\right)$ are represented in the ${ }^{238} \mathrm{U}$ decay chain (fig 1 ). The hydrochemistry of uranium is quite complex with many oxidations states, but only two are relevant in natural geochemical environments, +IV and +VI. The more oxidised form, uranyl $\left(\mathrm{UO}_{2}{ }^{2+}\right)$, is quite soluble in water, particularly under acid conditions and its mobility can be enhanced by complexation on organic matter, carbonates, phosphates and hydroxides. Under more reducing conditions, uranium is present in the oxidation state +IV and forms extremely insoluble hydroxide, $\mathrm{U}(\mathrm{OH})_{4}$, and oxide, $\mathrm{UO}_{2}$ species. Therefore, the concentration of free $\mathrm{U}^{4+}$ ions in natural water is negligible (Albu et al. 1997; Gascoyne 1989; Herczeg et al. 1988; Szabo \& Zapecza 1991). 


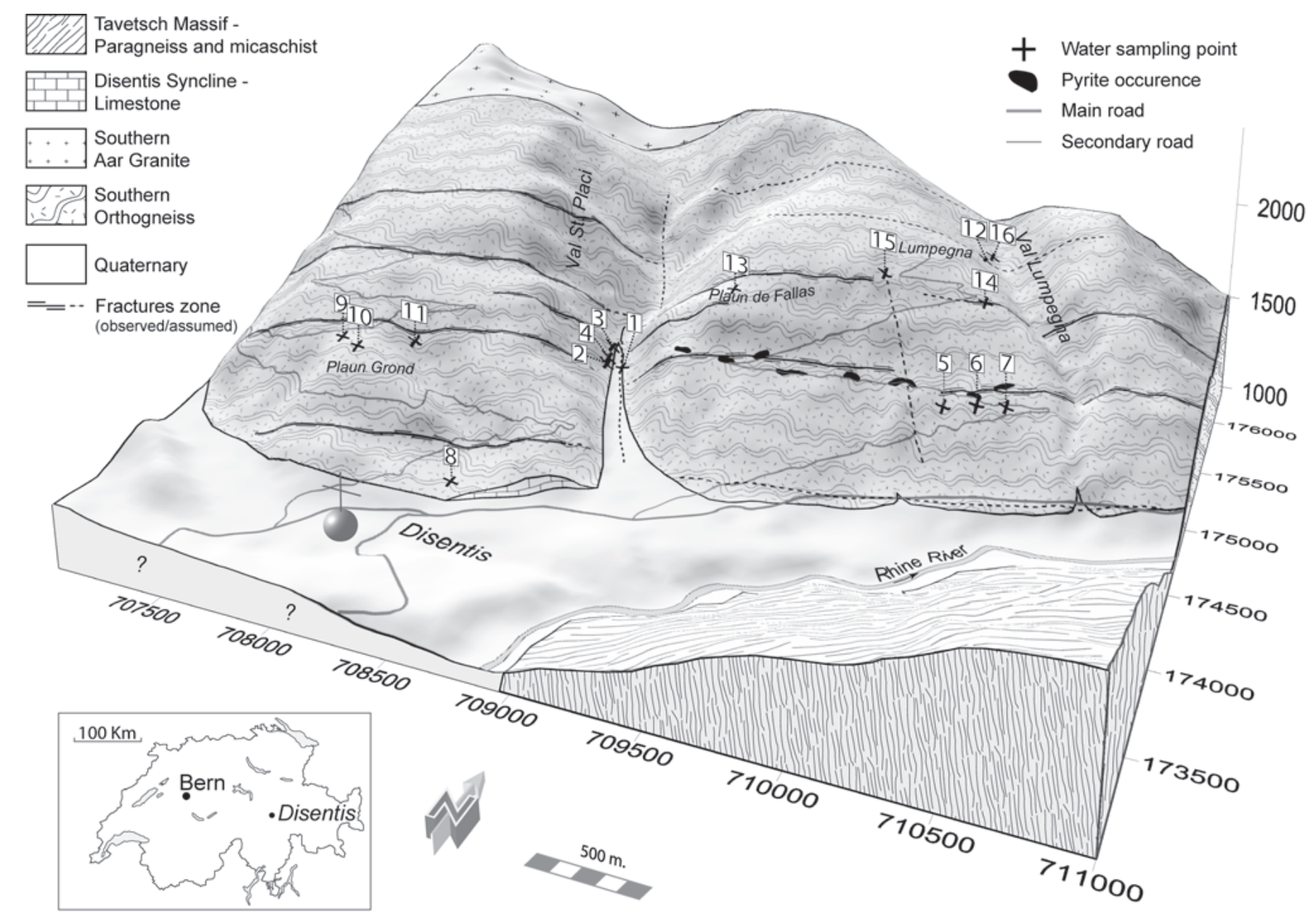

Fig. 2. Geological block diagram of the study area and location of the water sampling points.

In summary, it is important to note that radon, radium and uranium have contrasting geochemical behaviour: radon is highly soluble and mobile, but can easily be removed from water in open systems by degassing into the atmosphere; radium is mobile under reducing and acid conditions, while uranium is mobile in oxidising environments. Furthermore, the three radioisotopes are members of the same decay chain and thus interdependent of each other. Their contrasting behaviour, their interdependence, and the relatively short half-life of ${ }^{222} \mathrm{Rn}$, make these three radioisotopes valuable complementary tracers to study hydrogeological environments.

\section{Geological and hydrogeological setting}

\section{Location, topography and climate}

The study area is on the northern side of the Rhine Valley, near the city of Disentis in the Canton of Grisons in the eastern part of the Swiss Alps. St.Placidus spring is located in the narrow and steep St.Placi valley at an altitude of $1364 \mathrm{~m}$ (Swiss coordinates: 708580/174795). The mean annual temperature and precipitation, measured at the weather station of Disentis, are $5.9^{\circ} \mathrm{C}$ and $1036 \mathrm{~mm}$ respectively. The highest mountains in the area are Piz Cavardiras (2964 m) and Piz Acletta (2764 m).

\section{Geology}

Disentis is situated near the contact of two major geological units, the Aar Massif and the Tavetsch Massif (the German terms are 'Aarmassiv' and 'Tavetscher Zwischenmassiv') (Fig.2).

In this region, the Aar Massif is composed of the Southern Aar Granite (granite and granodiorite) and the Southern Orthogneiss (orthogneiss, diorite and amphibolite). The Tavetsch Massif is constituted of paragneiss and micaschist (Christ \& Nabholz 1955). Triassic and Middle Jurassic limestones are preserved in the syncline of Disentis between the two crystalline rock massifs. The main fractures are subvertical and oriented WSW-ENE (Eckardt 1957; Löw \& Wiss 1999).

The St. Placi valley consists of two-mica orthogneiss in 
Table 1 . Summary of the measured parameters and the analytical methods employed.

\begin{tabular}{llll} 
Parameters analysed & Method & Laboratory & Precision \\
\hline \hline $\mathrm{HCO}_{3}{ }^{-}$ & Titration & CLCG & $\pm 5 \%$ \\
$\mathrm{Ca}^{2+}, \mathrm{Mg}^{2+}, \mathrm{SO}_{4}{ }^{2-}, \mathrm{NO}_{3}{ }^{-}$and $\mathrm{Cl}^{-}$ & Ion chromatography & $C L C G$ & $\pm 5 \%- \pm 20 \%$ \\
$\mathrm{Na}^{+}, \mathrm{K}^{+}, \mathrm{Si}$ and $\mathrm{Fe}^{2+}$ & ICP-AES & $C L C G$ & $\pm 5 \%$ \\
${ }^{238} \mathrm{U}$ and trace elements & ICP-MS & $C L C Z$ & $\pm 15 \%$ \\
${ }^{18} \mathrm{O},{ }^{2} \mathrm{H}$ & Mass spectrometry & Hydrisotop & $\pm 0.15 \delta^{18} \mathrm{O} \%- \pm 1.5 \delta^{2} \mathrm{H} \%$ \\
${ }^{34} \mathrm{~S}$ & Mass spectrometry & UniWat & $\pm 5 \%$ \\
${ }^{222} \mathrm{Rn}$ (water) & Bubling \& $\alpha$-spectrometry in air & $\mathrm{CLCG}$ & See table 2 \\
${ }^{226} \mathrm{Ra}$ (water) & $\alpha$-spectrometry (Surbeck 2000) & $\mathrm{CLCG}$ & See table 2 \\
${ }^{226} \mathrm{Ra}$ (rock) & $\gamma$ - spectrometry & $\mathrm{CHYN}$ & See table 3 \\
\hline & ICP-MS: Induced Coupled Plasma - Mass & CLGC: Cantonal Laboratory of Canton Grisons \\
& Spectrometry & $C L C Z$ : Cantonal Laboratory of Canton Zürich
\end{tabular}

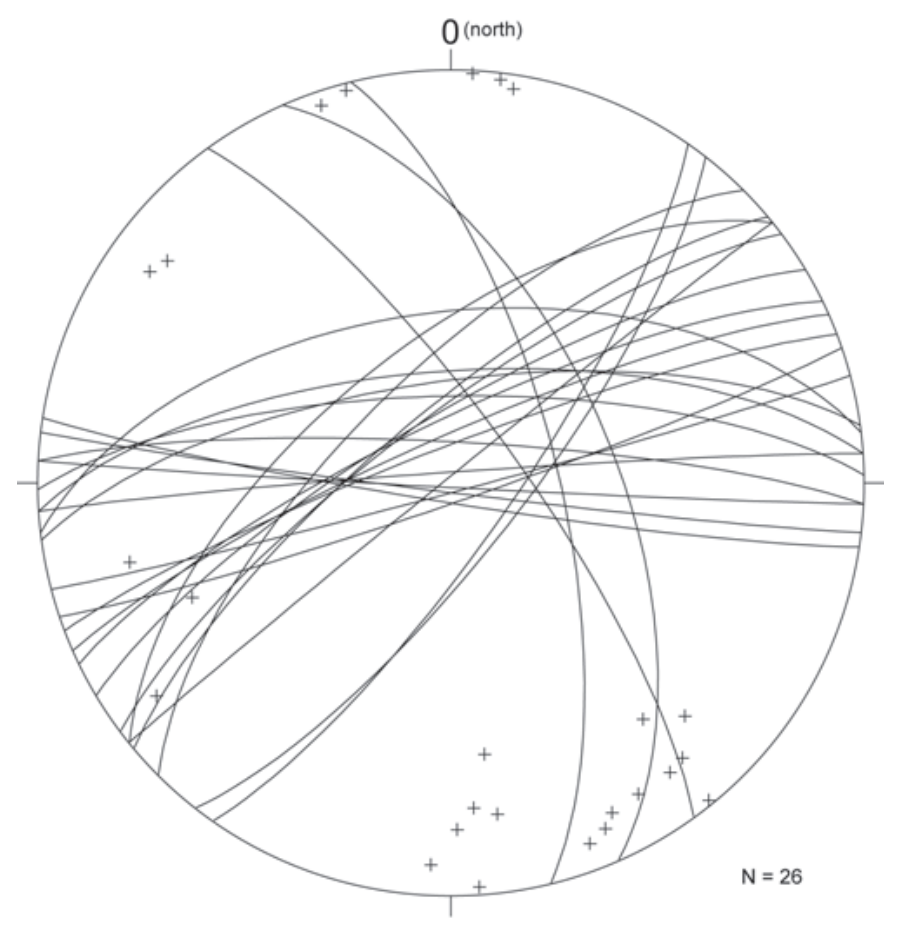

Fig. 3. Stereogram showing the orientation of fractures in the St. Placi valley (great circles and poles).

greenschist facies (Niggli 1944). Tourmaline-rich pegmatites occur $100 \mathrm{~m}$ south of the spring (Wehrli 1896). Fracture plane measurements (Fig. 3) confirmed the main (WSW-ENE) and secondary (WNW-ESE) orientation of the subvertical fractures. Weber (1924) mentions a fault parallel to St.Placi valley (N-S), passing through the spring. The rocks east of the spring are enriched in pyrite (Niggli 1944). During the present study, several pyrite occurrences have been mapped between St.Placi valley and Lumpegna valley.

\section{Hydrogeology}

In the Aar Massif, as in other crystalline rocks, the groundwater flow pattern is controlled by the orientation and hydraulic properties of the fractures and by the regional hydraulic gradient. Therefore, springs are often aligned along fractures and/or located at their intersections.

In the study area, the main and secondary fractures are oriented WSW-ENE and WNW-ESE respectively (Fig. 3). St. Placidus spring is related to a main fracture zone and probably receives its water from an ENE direction, i.e. the catchment is not simply defined by the topography but is mainly controlled by the fracturing. Most other springs are also aligned along this fracture zone.

In the area of Sedrun, located in the same geological setting about $20 \mathrm{~km}$ to the west, a hydrogeological study including tracer tests confirmed that groundwater flow mainly follows the WSW-ENE fractures (Frei \& Löw 2001).

Schweitzer (1916) and Högl (1980) report that St.Placidus consisted of two individual springs discharging from a fissure in the orthogneiss. Since the spring was developed in 1952, the natural outlets are no longer visible and the gneiss is covered locally by scree and alluvial deposits.

\section{Methods}

A variety of hydrochemical parameters, stable and radioactive isotopes have been measured for this study. Table 1 summarises the different parameters and analytical methods.

\section{Hydrochemistry and radioisotopes in the water}

Several field campaigns, including geological investigations and water sampling, were carried out from October 2002 to October 2003. The sampling sites are shown in fig. 2; their coordinates are given in table 2. During autumn 2002, all springs 


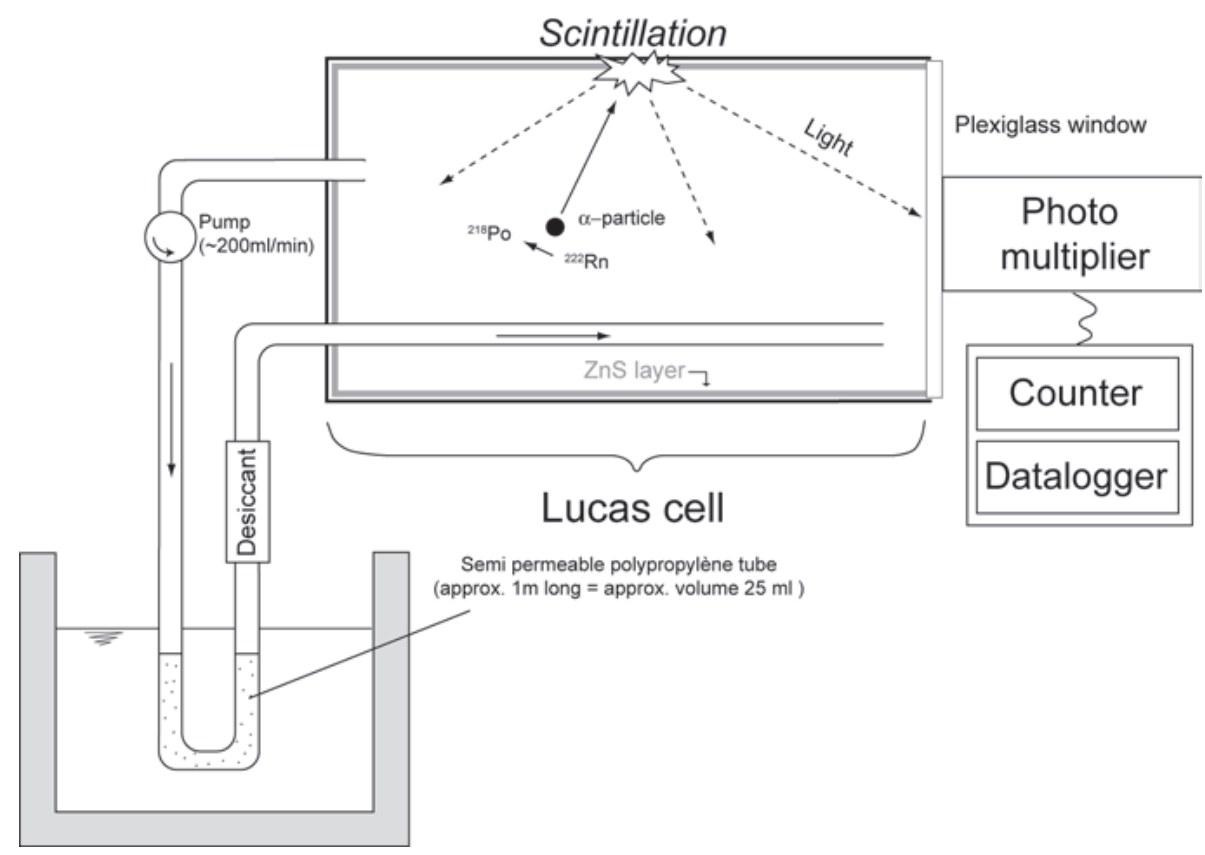

Fig 4. Principle of the radon continuous measurement device at St. Placidus spring.

in the area were sampled in order to characterise the different water types. From spring to autumn 2003, sampling focused on spring waters with high mineralisation and radon content (sampling points 1-8 in Fig. 2).

At every sampling event, a variety of physicochemical parameters (electrical conductivity, temperature, $\mathrm{pH}, \mathrm{O}_{2}$ ) were measured using standard field instruments. The discharge rates were determined with a bucket and stopwatch. Between August 2002 and October 2003 the discharge rate of St. Placidus spring was measured 10 times; fewer measurements were conducted at the other springs. Water samples were taken in $1 \mathrm{~L}$ PET bottles for chemistry, radium and uranium analysis, and glass bottles for radon and stable isotopes. Samples were kept cool until delivery to the different laboratories.

\section{Radioactivity in the rock}

Three orthogneiss rock and one iron hydroxide sludge samples were collected near St.Placidus spring in order to measure and compare their radioactivity with values given in the literature (Hirschi 1920). Two of the samples are rich in pyrite, while the third shows lower pyrite content. The sludge was collected $2 \mathrm{~m}$ downstream of the spring. A variety of radioactive isotopes $\left({ }^{234} \mathrm{Th},{ }^{226} \mathrm{Ra},{ }^{210} \mathrm{~Pb},{ }^{228} \mathrm{Ac},{ }^{40} \mathrm{~K},{ }^{137} \mathrm{Cs}\right)$ were measured both near the surface and in the core of each rock sample to assess the influence of weathering.

\section{Stable isotopes}

To determine the mean recharge altitude of St.Placidus spring, 5 water samples were collected in summer 2003, and their oxy- gen and hydrogen stable isotope ratios $\left(\delta^{18} \mathrm{O}\right.$ and $\left.\delta \mathrm{D}\right)$ were measured by means of mass spectrometry. The sulphur stable isotope ratio $\left(\delta^{34} \mathrm{~S}\right)$ of sulphate was measured in 3 water samples taken at springs 1 (St. Placidus), 2 and 6 on $25^{\text {th }}$ of September 2003, to assess whether the sulphur in sulphate originates from pyrite oxidation or evaporite dissolution.

\section{Continuous monitoring device}

To quantify the variability of selected parameters between the sampling events, continuous monitoring devices were installed at St.Placidus spring during September and October 2003. Electrical conductivity, temperature and radon were measured at intervals of 2 and 1 hours respectively. Radon was measured with a Lucas cell (Lucas 1957) operating once every hour for 5 minutes (Fig. 4).

\section{Results and discussion}

\section{Hydrochemistry}

Table 2 summarises the results of the chemical analyses. Springs 2-8 were sampled from October 2002 to October 2003. As the parameters vary little, only the more complete data from 2003 are presented here. The other springs (9-16) were only sampled in 2002.

St. Placidus spring had the highest mineralisation of all springs in the study, although a mean value of $255 \mathrm{mg} / \mathrm{L}$ of total dissolved solids (TDS) is still within the typical range of cold groundwaters from crystalline rocks (Matthess 2005). Calcium, magnesium and sulphate are the major ions. The relatively high 


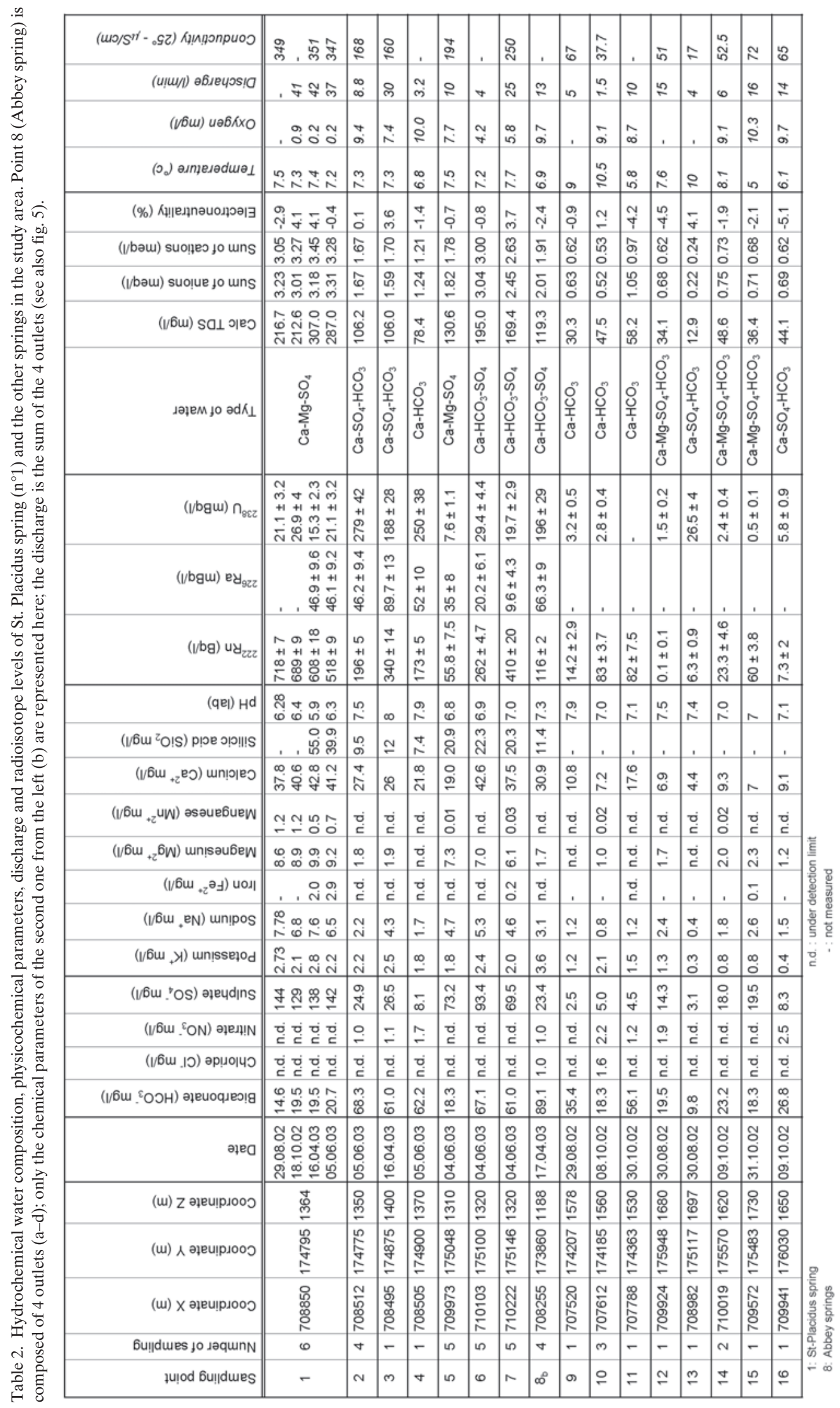




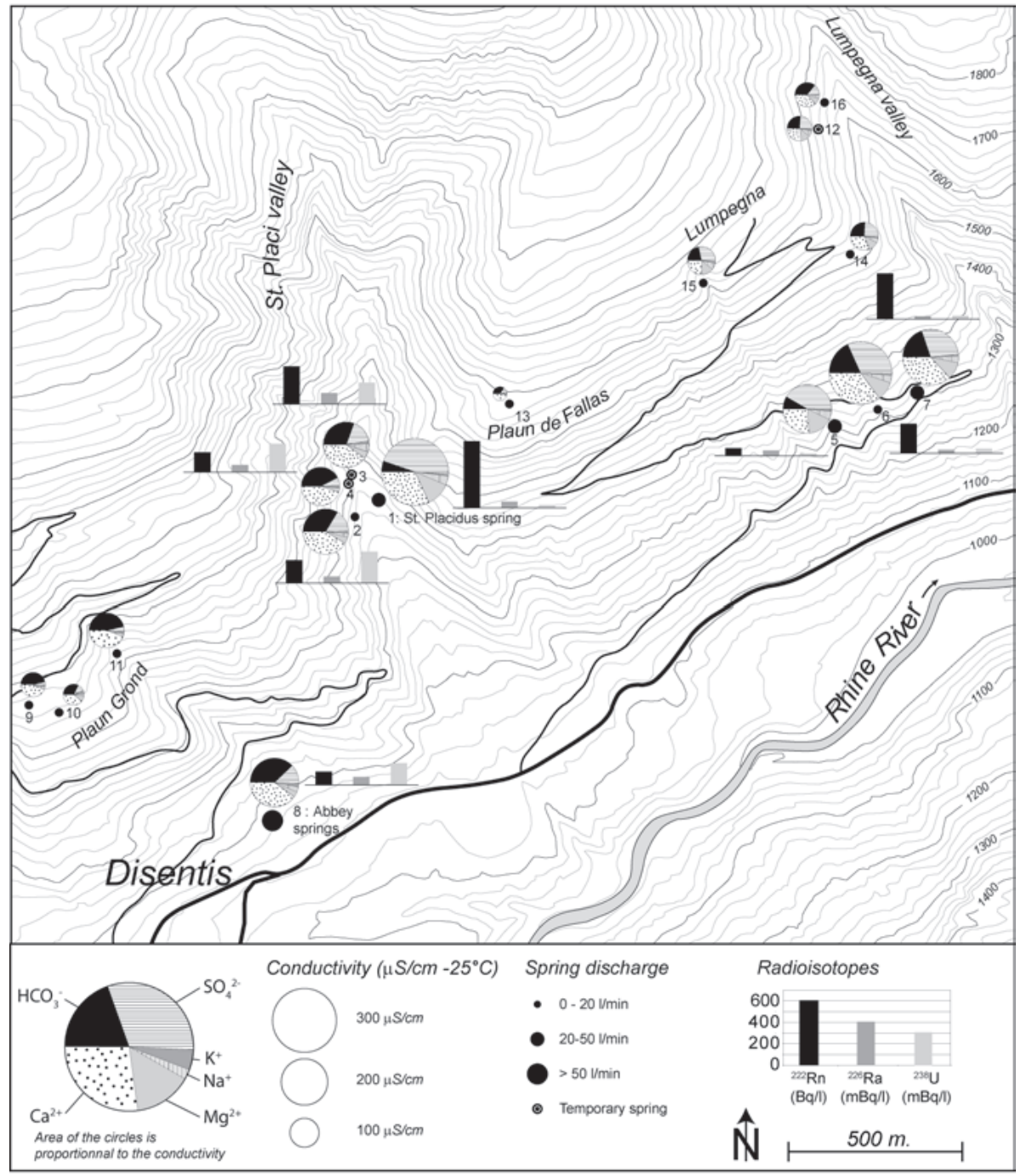

Fig 5. Hydrochemical map of the study area and radioisotope levels in the spring waters. The radioisotope activities in springs 9 to 16 are relatively low and are not presented here. The discharge of point 8 (Abbey springs) is the sum of 4 outlets, while the hydrochemical and isotopic data apply to point $8 \mathrm{~b}$ only (see also table 2 ). concentrations of $\mathrm{Fe}^{2+}$ and $\mathrm{Mn}^{2+}$ coincide well with the slightly acid $\mathrm{pH}$ and the very low level of dissolved oxygen (Krauskopf \& Bird 1995). The relatively high content of silicic acid can be attributed to increased silicate weathering under slightly acid conditions. The discharge is relatively constant and varies between 37 and $42 \mathrm{~L} / \mathrm{min}$ with a mean of $39.5 \mathrm{~L} / \mathrm{min}$. The water temperature measured at different times of the year is quite stable $\left(7.2-7.5^{\circ} \mathrm{C}\right)$ and slightly above the mean annual air temperature, suggesting a relatively deep circulation (Matthess 2005).

Apart from St.Placidus spring, three hydrochemical zones can be distinguished (Fig. 5, Table 2):

1) Eastern Zone: Springs 5-7 are most similar to St.Placidus spring. They are characterised by a $\mathrm{Ca}-\mathrm{Mg}-\mathrm{SO}_{4}$ or $\mathrm{Ca}-$ $\mathrm{HCO}_{3}-\mathrm{SO}_{4}$ water chemistry and moderate mineralisation (130-195 mg/L). However, compared to St.Placidus spring, the $\mathrm{pH}$ is neutral, oxygen levels are higher and the concentrations of reduced $\mathrm{Fe}$ and $\mathrm{Mn}$ cations in the water are close to or below the detection limits.
2) Western Zone: This zone includes the springs on the western side of St.Placi valley (2-4) and the springs further to the S and SW. Springs 2-4 differ significantly from St.Placidus spring. They show lower mineralisation (78-106 $\mathrm{mg} / \mathrm{L}$ ) and contain more bicarbonate and less sulphate; the $\mathrm{pH}$ is slightly basic, the oxygen levels are much higher, and the concentrations of $\mathrm{Fe}^{2+}$ and $\mathrm{Mn}^{2+}$ are correspondingly lower. Spring 8, located near the contact to the syncline of Disentis, shows similar characteristics. Springs 9-11 are characterised by very low mineralisation $(30-58 \mathrm{mg} / \mathrm{L})$ and a $\mathrm{Ca}-\mathrm{HCO}_{3}$ water type, which indicates local and shallow groundwater occurrence.

3) North-eastern Zone: Springs 12-16 are characterised by low to extremely low mineralisation (12-49 $\mathrm{mg} / \mathrm{L})$ and strong variations of temperature and discharge, which indicates very local and shallow groundwater occurrence. The dominant water composition in this zone is $\mathrm{Ca}-\mathrm{SO}_{4}$ $\mathrm{HCO}_{3}$. 


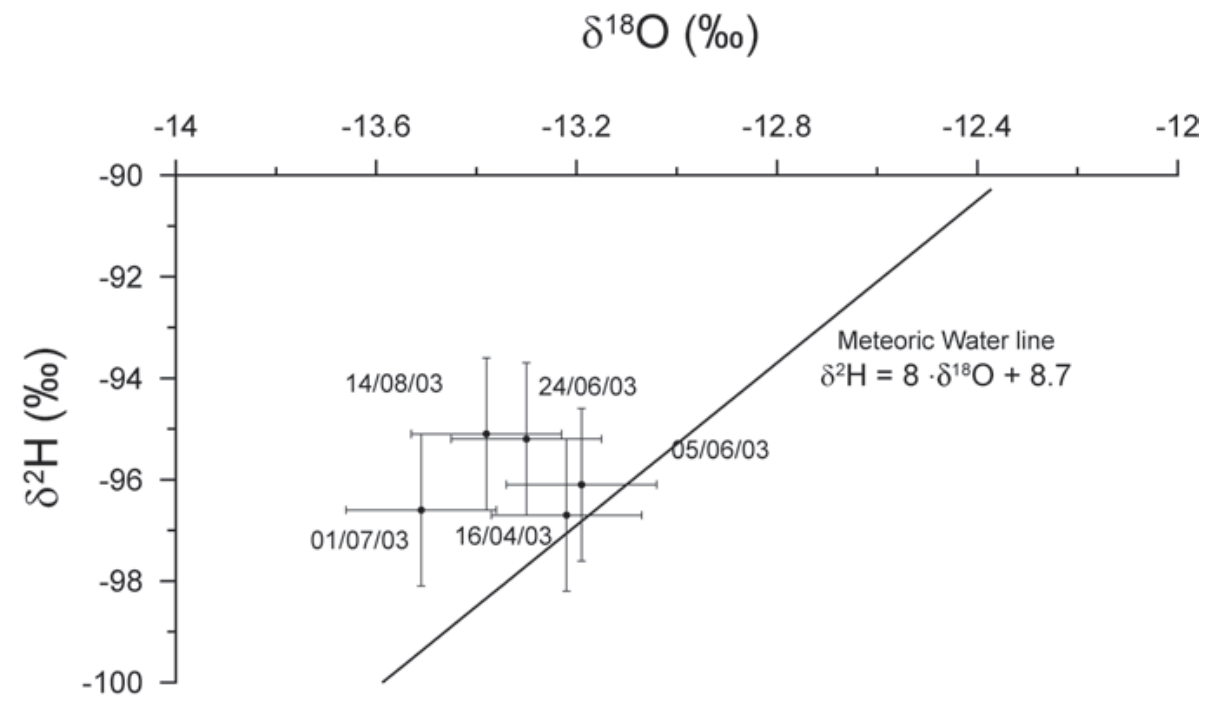

Fig. 6. Stable hydrogen and oxygen isotopic ratio for the water of St. Placidus spring, compared to the meteoric water line determined by Hartmann (1998) for the nearby region of Vals.

Table 3. Radioactivity in orthogneiss (1-3) and iron hydroxide sludge (4) samples collected near St. Placidus spring. Samples 1 and 3 are rich in pyrite while sample 2 shows a lower pyrite content.

\begin{tabular}{|c|c|c|c|c|c|c|c|c|c|c|c|c|c|c|}
\hline Sample & $\begin{array}{l}\text { Situation relative to } \\
\text { St-Placidus spring }\end{array}$ & Part of the sample & ${ }^{234} \mathrm{Th}$ & \pm & ${ }^{226} \mathrm{Ra}$ & \pm & ${ }^{210} \mathrm{~Pb}$ & \pm & ${ }^{228} \mathrm{Ac}$ & \pm & ${ }^{40} \mathrm{~K}$ & \pm & ${ }^{137} \mathrm{Cs}$ & \pm \\
\hline 1 & 10 m east & border & 15 & 5 & $<18$ & & 21 & 5 & 9 & 2 & 275 & 18 & 1 & 0.6 \\
\hline \multirow{2}{*}{2} & \multirow{2}{*}{40 m south-east } & border & 41 & 7 & 28 & 15 & 34 & 6 & 6 & 2 & 508 & 26 & 14 & 1 \\
\hline & & core & 13 & 6 & $<20$ & & 19 & 6 & 8 & 2 & 544 & 27 & $<0.8$ & \\
\hline 3 & 10 m east & border & 20 & 6 & 39 & 14 & 46 & 7 & 4 & 2 & 548 & 28 & 4.8 & 0.8 \\
\hline
\end{tabular}

\section{Stable isotopes}

Springs 1, 2 and 6 show similar sulphur isotope ratios $\left(\delta^{34} S\right)$ of $3.2,2.9$ and $4.1 \%$ respectively. The typical values for $\delta^{34} \mathrm{~S}$ in sulphate from marine evaporites (Middle Triassic to Jurassic) fall between 10 and $20 \%$. In pyrite from crystalline rocks, $\delta^{34} \mathrm{~S}$ is often around zero (Balderer 1985; Hartmann 1998; Pearson et al. 1991). Thus, the sulphate in these springs mainly originates from the oxidation of pyrite $\left(\mathrm{FeS}_{2}\right)$, which also explains the high $\mathrm{Fe}^{2+}$ concentrations of St.Placidus spring water. These findings support the hypothesis that the spring receives recharge from the zone of pyrite occurrences to the east (Fig. 2).

The oxygen and hydrogen stable isotope composition of St.Placidus spring is close to the meteoric water line (MWL) determined by Hartmann (1998) in Vals, about $30 \mathrm{~km} \mathrm{SW}$ of Disentis (Fig. 6). The mean recharge altitude for a given water supply can be estimated with the empiric formulae 1 and 2, which have been proposed for the central Grisons and the Engadine (Pearson et al. 1991).

(1) Altitude $=\left(-357.14 \cdot \delta^{18} \mathrm{O}\right)-2893$

(2) Altitude $=\left(-37.73 \cdot \delta^{2} \mathrm{H}\right)-1713$
The mean recharge altitudes obtained with the average values of the five samples from St. Placidus spring are $1860 \mathrm{~m}$ (formula 1) and $1900 \mathrm{~m}$ (formula 2). Although these altitudes seem coherent, the results must be considered carefully because the formulae were not established for the region of Disentis and the confidence interval is about $95 \%$ due to the lack of data and the mountainous character of the region.

\section{Radioactivity in the rock}

Hirschi (1920) explained the high radon levels in St. Placidus spring by high radium levels $(360 \mathrm{~Bq} / \mathrm{kg})$ in the rocks of St. Placi valley. Several studies assessed the mean values of ${ }^{226} \mathrm{Ra}$ in crystalline rocks of Switzerland: $109 \mathrm{~Bq} / \mathrm{kg}$ (Hirschi 1920) and $85 \mathrm{~Bq} / \mathrm{kg}$ (Schärli 1989) for granite, and $50 \mathrm{~Bq} / \mathrm{kg}$ for gneiss (Schärli 1989).

Table 3 gives the values measured during the present study. The measured radium levels in the orthogneiss samples are about 10 times lower than the activity given by Hirschi and two to three times lower that the mean values for gneiss and granite. This discrepancy may partly reflect the heterogeneous dis- 

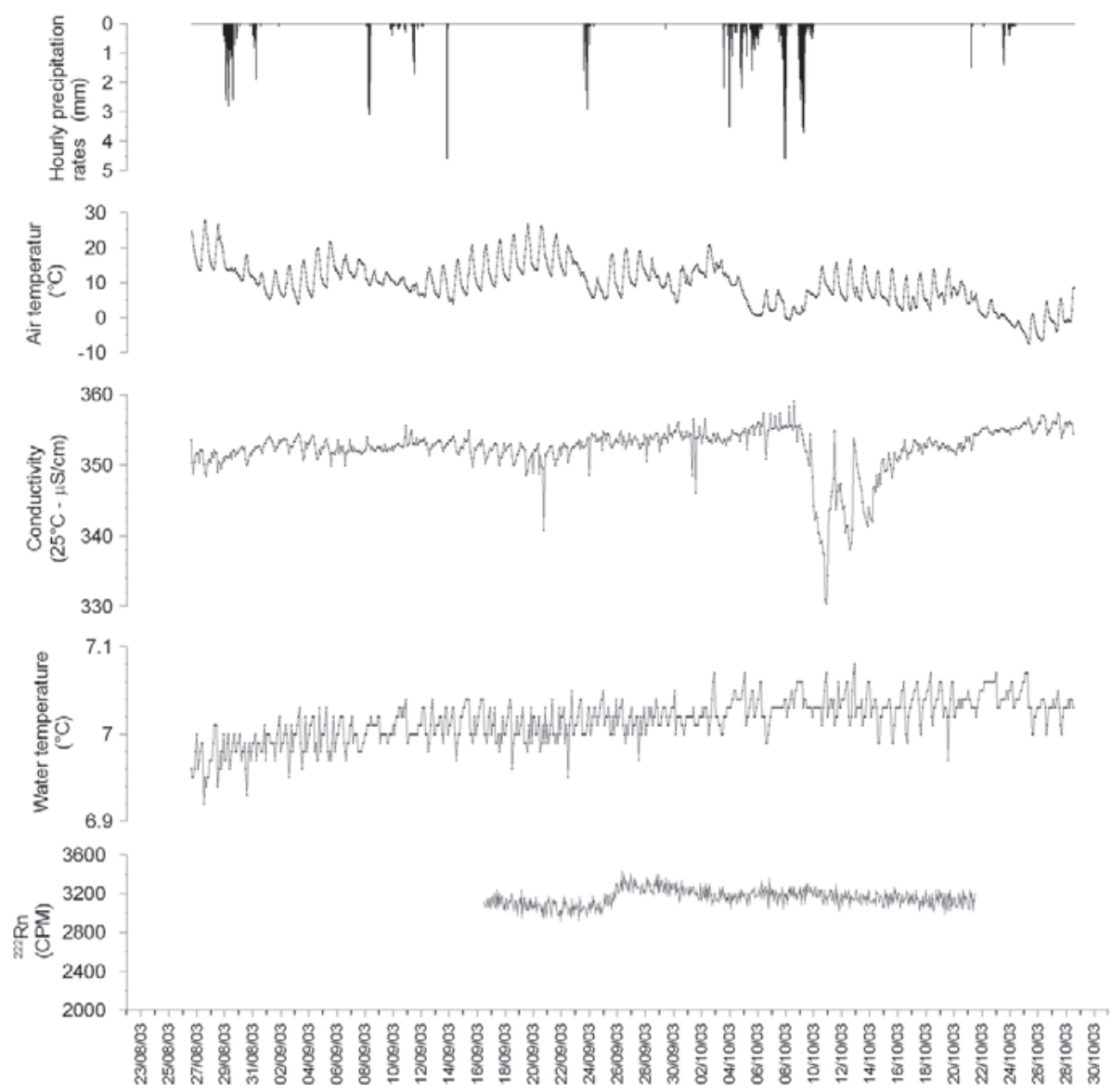

Fig. 7. Precipitation measured at the weather station of Disentis, and variations of conductivity, temperature and ${ }^{222} \mathrm{Rn}$ recorded at St. Placidus spring. CPM: counts per minutes.

tribution of radium in the orthogneiss, and the resulting difficulty to obtain representative samples. However, the result also suggests that high radon levels in St. Placidus spring cannot be solely attributed to generally high radium levels in the surrounding rock. A regional radium anomaly in the rock would cause similarly high levels of radon in all springs in the area, which is not the case. Consequently, the radon anomaly in St. Placidus spring must be explained by other, more local mechanisms.

The observed high ${ }^{226} \mathrm{Ra}$ activity in the sample of iron and manganese hydroxide sludge confirms the strong capacity of these hydroxides to adsorb and accumulate radium, even if its concentration in the water is relatively low.

\section{Radioactivity in the water}

The mean values of radionuclides in groundwater from Grisons are $31 \mathrm{mBq} / \mathrm{L}$ for ${ }^{238} \mathrm{U}, 15 \mathrm{mBq} / \mathrm{L}$ for ${ }^{226} \mathrm{Ra}$, and 15 $\mathrm{Bq} / \mathrm{L}$ for ${ }^{222} \mathrm{Rn}$ (Deflorin 2004) but values measured in this study were generally higher (Table 2 ). The highest radon levels, 518-718 Bq/L, were found in St. Placidus spring, while the uranium and radium levels were not exceptionally high, 21 and $46 \mathrm{mBq} / \mathrm{L}$ respectively. The springs of the eastern zone $\left(\mathrm{n}^{\circ}\right.$ 5-7) also showed relatively low radium and uranium concen- trations but sometimes high radon levels, particularly spring $\mathrm{n}^{\circ}$ 7. The north-eastern zone was generally poor in these radioelements, although some springs showed increased levels of uranium $\left(n^{\circ} 13\right)$ or radon $\left(n^{\circ} 15\right)$.

The springs on the western side of the St. Placi valley $\left(\mathrm{n}^{\circ}\right.$ $2-4$ ) and spring $n^{\circ} 8$ are very rich in uranium and radium, and also show relatively high radon levels. It is important to note that these springs contain more radium but less radon than St. Placidus spring.

As the ${ }^{222} \mathrm{Rn}$ activity in St. Placidus spring is 4 orders of magnitude higher than those of ${ }^{226} \mathrm{Ra}$, the ${ }^{222} \mathrm{Rn}$ levels cannot be attributed to ${ }^{226} \mathrm{Ra}$ dissolved in the water. There must be a ${ }^{226} \mathrm{Ra}$ reservoir, probably disseminated along the fracture network and in contact with groundwater, whereby radon can easily be dissolved in water. As the half-life of ${ }^{222} \mathrm{Rn}$ is quite short (4 days) this reservoir must be located near the spring.

\section{Variability of temperature, conductivity and radon}

Continuous measurements at St. Placidus spring resulted in detailed time-series of temperature, conductivity and ${ }^{222} \mathrm{Rn}$ over a 2-month period (Fig. 7). Temperature is relatively stable but increases steadily by $0.2{ }^{\circ} \mathrm{C}$ from the end of August to the end of October 2003, suggesting that the temperature of the spring 


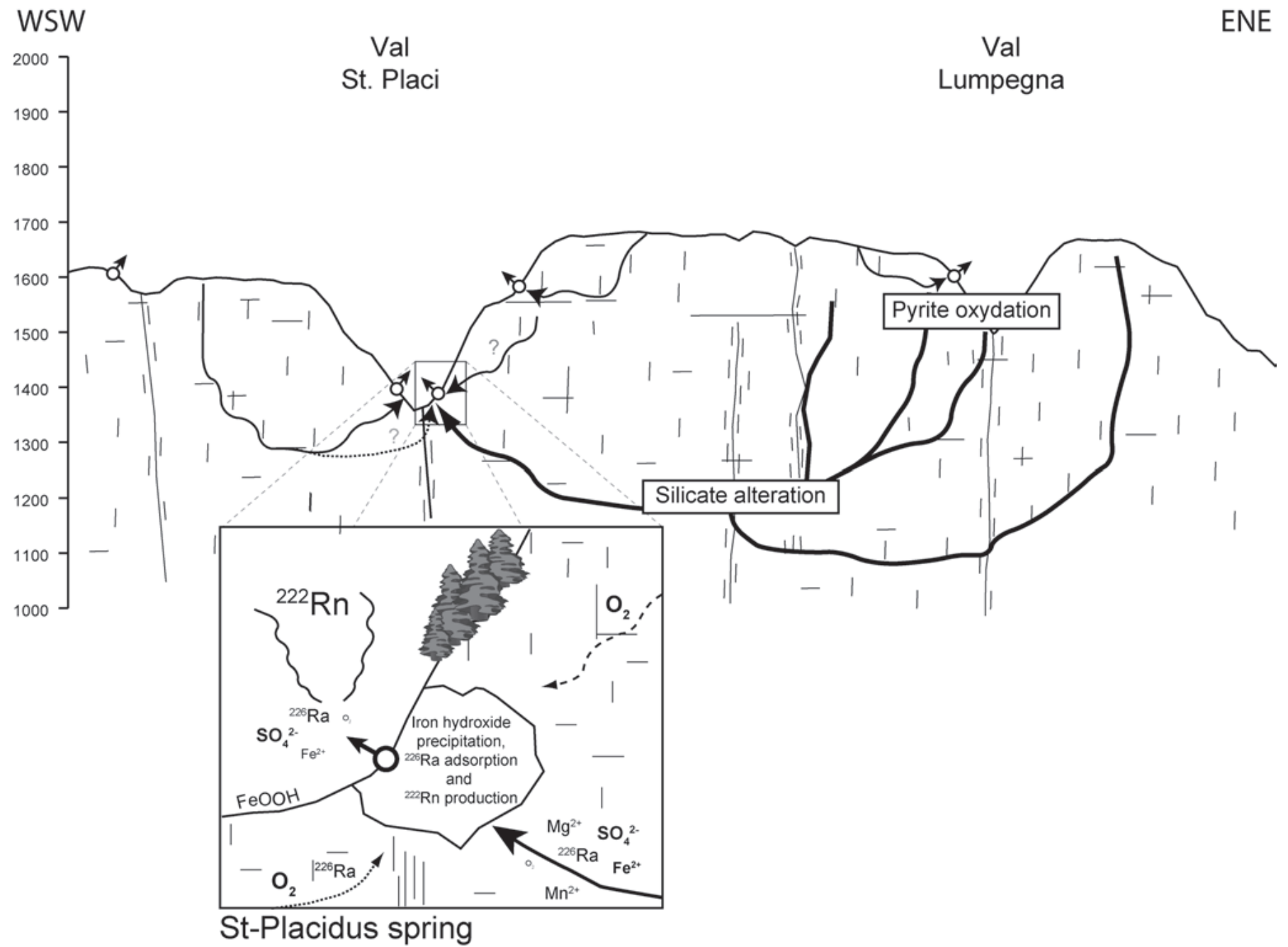

Fig. 8. Conceptual model showing the groundwater flow system and the geochemical processes causing the high radon content of St. Placidus spring. In the small figure, font size represents the concentration.

water is slightly influenced by the air temperature with a delay of more than 2 months (maximum air temperature occurs in August). The daily variations of $0.05^{\circ} \mathrm{C}$ probably reflect variations of the air temperature directly at the springhead.

In contrast, conductivity is not as stable as the discrete measurements had suggested: A sharp decrease of $30 \mu \mathrm{S} / \mathrm{cm}$ occurred between the $10^{\text {th }}$ and $12^{\text {th }}$ of October, followed by two additional increase-decrease cycles. This variation is probably due to rainfall events from the $8^{\text {th }}$ to $10^{\text {th }}$ of October. This observation indicates that low mineralised water can enter the system a short time after intense rainfall and induce a sharp decrease in conductivity and, very probably, an increase of oxygen in the spring water, although this latter effect has not yet been observed directly.

Radon levels do not show significant variations implying continuous generation of ${ }^{222} \mathrm{Rn}$ by disintegration of ${ }^{226} \mathrm{Ra}$. The minor radon variation of the $26^{\text {th }}$ of September cannot be interpreted, as it coincides with a field visit, which might have disturbed the measurement device.

\section{Conceptual model and conclusions}

The results presented above demonstrate that radium activity in the fractured orthogneiss aquifer is not sufficiently high to produce the observed radon levels in St. Placidus spring. The concentration of free radium in the water is grossly insufficient to explain this radon anomaly. Deflorin (2004) calculated that a radium activity of $2.1 \cdot 10^{8} \mathrm{~Bq}$ would be required to produce the observed radon level $(650 \mathrm{~Bq} / \mathrm{L})$ in St.Placidus spring with a mean discharge of $40 \mathrm{~L} / \mathrm{s}$. Consequently, there must be a productive radium reservoir on that order of magnitude, which contains significantly more radium than the bulk rock mass. 
Such a reservoir probably consists of radium cations adsorbed on Fe/Mn (hydr)oxides, deposited in the fissures upgradient from the spring. As the half-life of ${ }^{222} \mathrm{Rn}$ is only 4 days, these deposits must be located near the spring. The precipitation of such (hydr)oxides can be directly observed at the spring outlet, where the reduced water $\left(0.2-0.9 \mathrm{mg} / \mathrm{L} \mathrm{O}_{2}\right)$ comes in contact with the air. However, the observed variability of electrical conductivity at the spring (Fig. 7) also suggests that low mineralised, probably oxygen-rich water can enter the flow system during and after rainfall events, and thus cause precipitation of Fe/Mn (hydr)oxides by oxidation inside the aquifer.

A conceptual model of groundwater circulation towards St.Placidus spring and the geochemical processes leading to high radon levels in the spring water is presented in Fig. 8: Oxygen-rich water from rainfall and snowmelt infiltrates at a mean altitude of about $1900 \mathrm{~m}$ and circulates through a network of fractures in pyrite-rich orthogneiss.

As a consequence of pyrite oxidation, water loses most of its oxygen and becomes more acid and rich in iron and sulphate (Krauskopf \& Bird 1995):

(3) $2 \mathrm{H}_{2} \mathrm{O}+2 \mathrm{FeS}_{2}+7 \mathrm{O}_{2} \rightarrow 2 \mathrm{Fe}^{2+}+4 \mathrm{H}^{+}+4 \mathrm{SO}_{4}{ }^{2-}$

The acid $\mathrm{pH}$ of water increases the dissolution of silicates, particularly micas, chlorite and feldspars, along its pathway. The weathering of albite may serve as an example (Krauskopf \& Bird 1995):

(4) $2 \mathrm{Na}\left[\mathrm{AlSi}_{3} \mathrm{O}_{8}\right]+2 \mathrm{H}^{+}+\mathrm{H}_{2} \mathrm{O}=\mathrm{Al}_{2}\left[(\mathrm{OH})_{4} / \mathrm{Si}_{2} \mathrm{O}_{5}\right]+4 \mathrm{SiO}_{2}$ $+2 \mathrm{Na}^{+}$

Similar dissolution processes also explain the increased levels of silicic acid and various metal cations (e.g. $\mathrm{Na}^{+}, \mathrm{Mg}^{2+}, \mathrm{Fe}^{2+}$ ) in the water of St.Placidus spring. The relatively small concentrations of $\mathrm{Mn}^{2+}$ may result from several sources, such as biotite and pegmatites with tourmaline, which occur in the area. This would also explain the increased fluoride concentration in the spring water $(0.8 \mathrm{mg} / \mathrm{L})$.

The $\mathrm{Fe}^{2+}$ and $\mathrm{Mn}^{2+}$ dissolved in the reduced groundwater precipitate as oxides and hydroxides (e.g. $\mathrm{FeOOH}, \mathrm{Fe}_{2} \mathrm{O}_{3}$, $\mathrm{MnO}_{2}$ ) near the spring, mainly during rainfall events or snowmelt, when oxygen-rich water enters the system. These deposits are probably disseminated along a network of fractures. Dissolved radium cations $\left(\mathrm{Ra}^{2+}\right)$ are adsorbed on these deposits and produce ${ }^{222} \mathrm{Rn}$ at a constant rate. Radon is highly soluble and mobile and arrives at the spring after a short transit through the aquifer.

In conclusion, two aspects are crucial to explain the high radon levels in St.Placidus spring: (1) the high $\mathrm{Fe}^{2+}$ (and $\mathrm{Mn}^{2+}$ ) concentration in the reduced groundwater, originating from pyrite oxidation, and (2) the hydrogeological setting, which allows oxygen-rich water to enter the fractured aquifer near the spring and cause precipitation of Fe/Mn (hydr)oxides. Without this occasional oxygen supply, there would be no such precipitation inside the aquifer, but only at the spring outlet and further below. On the other hand, if the groundwater were more oxic in general, Fe/Mn precipitation by oxidation would occur in a more diffuse way over the entire aquifer. This would not change the gross radon production in the system, but most of the ${ }^{222} \mathrm{Rn}$ would decay before reaching the spring. These findings are consistent with other studies, which also demonstrated the important role of Fe/Mn (hydr)oxides in radionuclide enrichment (Schott \& Wiegand 2003). High radon levels at many other springs can probably also be attributed to the presence of iron and manganese oxides and hydroxides.

This study also showed that radioisotopes of the ${ }^{238} \mathrm{U}$ series represent useful complementary tracers to better understand hydrogeological environments. The contrasting hydrochemical behaviour of uranium, radium and radon, their interdependency and the relatively short half-life of ${ }^{222} \mathrm{Rn}$ make it possible to identify and localise geochemical processes in aquifer systems.

\section{Acknowledgements}

We thank Dr. Otmar Deflorin and the Cantonal Laboratories of Grisons and Zurich for various analyses and good cooperation, Prof. Martin Burkhard $(\dagger)$, Prof. Daniel Hunkeler and Frederic Bossy for valuable suggestions and discussions, and the people who helped us in the field, particularly Dr. Charles Robert-Charrue. We are grateful to the city and Abbey of Disentis for various information and permissions, and for the warm welcome. We thank William Winston for final language corrections.

\section{REFERENCES}

Albu, M., Banks, D. \& Nash, H. 1997: Mineral and thermal groundwater resources. London, Chapman \& Hall.

Almeida, R. M. R., Lauria, D. C., Ferreira, A. C. \& Sracek, O. 2004: Groundwater radon, radium and uranium concentrations in Regiao dos Lagos, Rio de Janeiro State, Brazil. Journal of Environmental Radioactivity 73, 323-334.

Ames, L. L., Mcgarrah, J. E., Walker, B. A. \& Salter, P. F. 1983: Uranium and radium sorption on amorphous ferric oxyhydroxide. Chemical Geology 40, 135-148.

Balderer, W. 1985: Sondierbohrung Böttstein. Ergebnisse der Isotopenuntersuchungen zur hydrogeologischen Charakterisierung der Tiefengrundwässer. Nagra Technisches Bericht 85-06. Baden.

Christ, P. \& Nabholz, W. 1955. Swiss general geological map,1:200’000. Kümmerly \& Frei, Bern.

Clever, H. L. 1979: IUPAC Solubility Data Series, Vol.2: Krypton, Xenon and Radon. Oxford, Pergamon Press.

Deflorin, O. 2004: Natürliche Radionuklide in Grundwässern des Kantons Graubünden. PhD Thesis, Center of hydrogeology, University of Neuchâtel.

Eckardt, P. M. 1957: Zur Talgeschichte des Tavetsch - seine Bruchsysteme und Jungquartären Verwerfungen. PhD Thesis, University of Zürich. Pp.

Eisenlohr, L. \& Surbeck, H. 1995: Radon as a natural tracer to study transport processes in a karst system. An example in the Swiss Jura. Comptes rendus de l'Académie des sciences de Paris 321, série IIa: 761-767.

Etcheverry, D. \& Perrochet, P. 2000: Direct simulation of groundwater transittime distributions using the reservoir theory. Hydrogeology Journal 8 (2), 200-208.

Frei, B. \& Löw, S. 2001: Störzonen im südlichen Aar-Massiv. Eclogae geologicae Helvetiae 94(1), 13-28.

Gascoyne, M. 1989: High levels of uranium and radium in groundwaters at Canada's Underground Research Laboratory, Lac du Bonnet, Manitoba, Canada. Applied Geochemistry 4, 577-591. 
Hartmann, P. 1998: Mineralwasservorkommen im nördlichen Bündnerschiefergebiet mit Schwerpunkt Valsertal. PhD Thesis, Diss. $N^{\circ} 12632$, Eidgenössische Technische Hochschule Zürich (ETHZ).

Herczeg, A. L., Simpson, H. J., Anderson, R. F., Trier, R. M., Mathieu, G. G. \& Deck, B. L. 1988: Uranium and radium mobility in groundwaters and brines within the Delaware Basin, southeastern New Mexico, U.S.A. Chemical Geology 72, 181-196.

Hirschi, H. 1920: Radioaktivität einiger Schweizergesteine. Vierteljahrschrift der Naturforschenden Gesellschafft in Zürich, 209-247 \& 545-572.

Högl, O. 1980: Die Mineral- und Heilquellen der Schweiz. Bern und Stuttgart, Paul Verlag.

Krauskopf, K. B. \& Bird, D. K. 1995: Introduction to geochemistry. New York.

Langmuir, D. \& Riese, A. C. 1985: The thermodynamic properties of radium. Geochimica et cosmochimica acta 49, 1593-1601.

Lauria, D. C., Almeida, R. M. R. \& Sracek, O. 2004: Behavior of radium, thorium and uranium in groundwater near the Buena Lagoon in the Coastal Zone of the State of Rio de Janeiro, Brazil. Environmental Geology 47(1), 11.

Löw, S. \& Wiss, R. 1999: Vorerkundung und Prognose der Basistunnels am Gotthard und am Lötschberg. Rotterdam, A.A. Balkema.

Lucas, H. F. 1957: Improved low-level alpha-scintillation counter for radon. Review of Scientific Instruments 28, 680-683.

Martin, A. J., Crusius, J., Mcnee, J. J. \& Yanful, E. K. 2003: The mobility of radium-226 and trace metals in pre-oxidized subaqueous uranium mill tailings. Applied Geochemistry 18, 1095-1110.

Matthess, G. 2005: Die Beschaffenheit des Grundwassers, 3. Auflage, Lehrbuch der Hydrogeologie. Berlin.

Müller, I. 1971: Geschichte der Abtei Disentis. Von den Anfängen bis zur Gegenwart. Zürich / Köln, Benziger.

Niggli, E. 1944: Das westliche Tavetscher Zwischenmassiv und der angrenzende Nordrand des Gotthardmassivs; petrographisch-geologische Untersuchungen. Bulletin Suisse de Minéralogie et de Pétrographie 24(1-2), 58-301.
Pearson, F. J., Balderer, W., Loosli, H., Lehamnn, B., Matter, A., Peters, T., Schmassmann, H. \& Gautschi, A. 1991: Applied isotope hydrogeology, a case study in northern Switzerland. Elsevier.

Schärli, U. 1989: Geothermische Detailkartierung (1:100'000) in der zentralen Nordschweiz, mit besonderer Berücksichtigung petrophysikalischer Parameter. PhD Thesis, ETHZ, Nr. 8941.

Schott, B. \& Wiegand, J. 2003: Processes of radionuclide enrichment in sediments and groundwaters of Mont Vully (Canton Fribourg, Switzerland). Eclogae Geologicae Helvetiae 96, 99-107.

Schweitzer, A. 1916: Radioaktivität der Heilquellen der Schweiz. Annales de la Société Suisse de balnéologie et climatologie. H. R. Sauerländer, Aarau.

Sturchio, N. C., Banner, J. L., Binz, C. M., Heraty, L. B. \& Musgrove, M. 2001: Radium geochemistry of ground waters in Palaeozoic carbonate aquifers, midcontinent, USA. Applied Geochemistry 16, 109-122.

Szabo, Z. \& Zapecza, O. 1991: Geologic and geochemical factors controlling uranium, radium-226, and radon-222 in ground water, Newark Basin, New Jersey. US Geological Survey Bulletin 1971, 243-265.

UNSCEAR 2000: United Nations Scientific Committee on the Effects of Atomic Radiation. Sources and effects of incrising radiation. Vol. 1, $654 \mathrm{pp}$.

Weber, F. 1924. Geologische Karte des Tödi-Vorderrheintal-Gebietes, 1:50'000.

Wehrli, L. 1896: Dioritgebiet von Schlans bis Disentis. Matériau pour la carte géologique de la Suisse 6.

Manuscript received October 15, 2006

Revision accepted February 9, 2007

Published Online First August 13, 2007 